\title{
A Supramolecular Fluorescence Sensor for Pyrovanadate as a Functional Model of Vanadium Haloperoxidase
}

\author{
Xiao-an Zhang, Wolf-D. Woggon* \\ Department of Chemistry, University of Basel, St. Johanns-Ring 19,CH- 4056 Basel, Switzerland \\ E-mail:wolf-d.woggon@unibas.ch

\section{Supporting Information}

Synthesis of Tris-(2- (N'-pyren-1yl-methyl-guanidinium)-ethyl)- amine tri-chloride (2). 2 was synthesized through the thiourea intermediate 5, which was obtained from the coupling of trisisothiocyanate $\mathbf{4}$ with pyrene-1-methylamine. The central nitrogen of $\mathbf{5}$ was protected by protonation with HI; the following methylation therefore only occurred at sulfur to give S-methyl isothiourea derivative 6 . Without purification, $\mathbf{6}$ reacted with ammonia in a sealed tube and the resulting final product $\mathbf{2}$ was purified and converted to chloride salt via ion exchange chromatography (Scheme 1).

\section{Scheme 1}
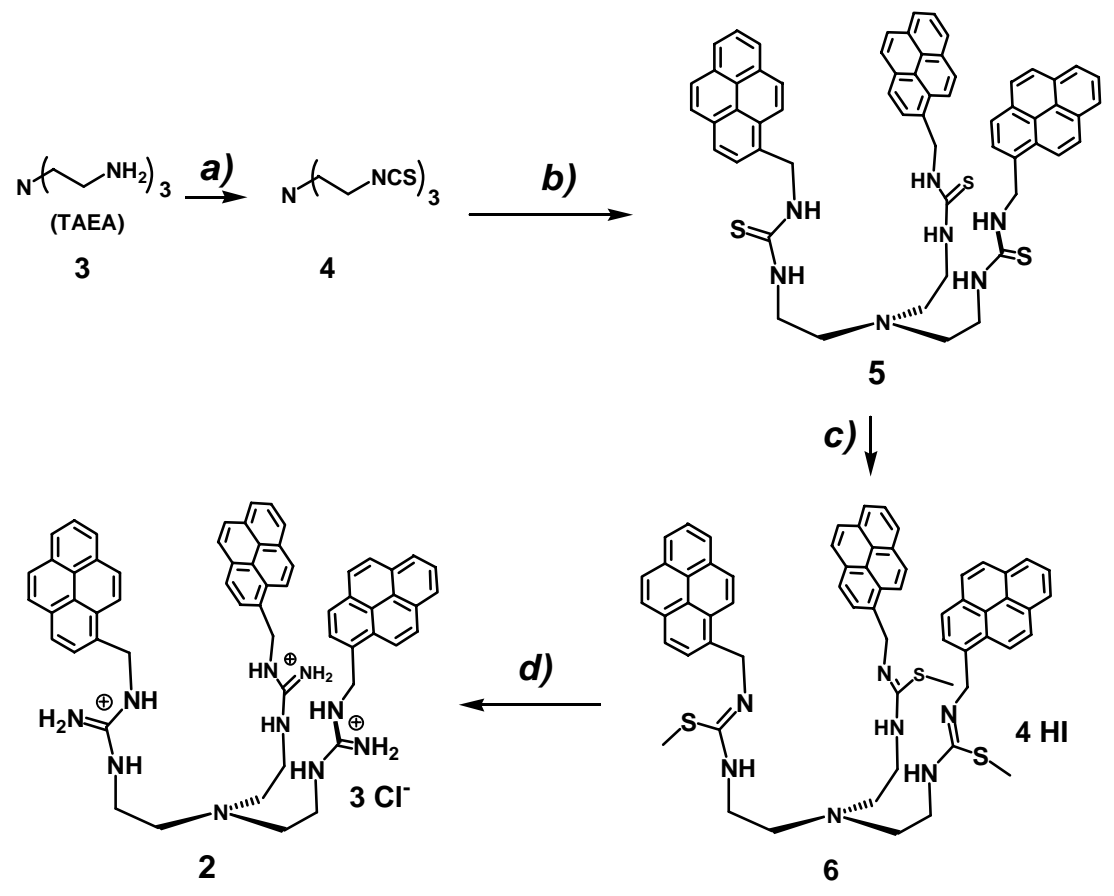

Tris-(2-isothiocyanate-ethyl)amine (4). (2-Aminoethyl) amine $3(0.29 \mathrm{~g}, 2.00 \mathrm{mmol})$ dissolved in $8.0 \mathrm{ml}$ of THF was added dropwise to a solution of DCC $(1.65 \mathrm{~g}, 8 \mathrm{mmol})$ and $3.2 \mathrm{ml}$ of $\mathrm{CS}_{2}$ (large excess) in $8.0 \mathrm{ml}$ of THF at $-10^{\circ} \mathrm{C}$. The reaction mixture was warmed up to room temperature and was stirred overnight. $5 \mathrm{ml}$ of ether was added in to precipitate the solid of N,N'-dicyclohexyl-thiourea, which was filtered off and 
washed with $5 \mathrm{ml}$ ether. The filtrate was evaporated and the resulting solid was washed with hexane. Purification by chromatography on silica gel (chloroform) gave $0.42 \mathrm{~g}$ amine $4(76 \%)$ as a yellow solid. mp: 48-49 ${ }^{\circ} \mathrm{C} ;{ }^{1} \mathrm{H}$ NMR (400 MHz, $\mathrm{CDCl}_{3}$ ): 2.97 (t, $\left.J=6.2 \mathrm{~Hz}, 6 \mathrm{H}, \mathrm{N}-\mathrm{CH}_{2}\right) ; 3.60$ (t, $J=6.2 \mathrm{~Hz}, 6 \mathrm{H}, \mathrm{CH}_{2}-$ NCS). ${ }^{13} \mathrm{C}$ NMR (100 MHz, $\left.\mathrm{CDCl}_{3}\right): 44.7\left(\mathrm{~N}^{-C_{2}}\right) ; 54.9\left(\mathrm{CH}_{2}-\mathrm{NCS}\right) ; 133.5$ (NCS). FAB-MS (m/z): 273 $\left(\mathrm{M}^{+}, 25.8\right) ; 200$ (100). EA. calc. for $\mathrm{C}_{9} \mathrm{H}_{12} \mathrm{~N}_{4} \mathrm{~S}_{3}$ : C 39.68, H 4.44, N 20.57; found: C 39.88, H 4.41, N 20.66. IR (KBr): 2201, $2120 \mathrm{~cm}^{-1}$.

Tris-(2- (N'-pyren-1yl-methyl-thiourea)-ethyl)- amine (5). Tris-(2-isothiocyanate-ethyl)amine (4) (210 $\mathrm{mg}, 0.77 \mathrm{mmol})$, 1-pyrenemethylamine hydrochloride $(606.3 \mathrm{mg} 2.27 \mathrm{mmol})$ and $330 \mu \mathrm{l}$ triethylamine were mixed in $30 \mathrm{ml} \mathrm{CH}_{2} \mathrm{Cl}_{2}$ and stirred under argon for one week. All the volatiles were removed in vacuo and the residue was purified by flash chromatography (silica gel, $\mathrm{CH}_{2} \mathrm{Cl}_{2} / \mathrm{MeOH}$ gradient from 100:0 to 100:2) to afford $619.5 \mathrm{mg} 5(83.2 \%)$ as a yellow solid. ${ }^{1} \mathrm{H}-\mathrm{NMR}\left(600 \mathrm{MHz}, \mathrm{CD}_{2} \mathrm{Cl}_{2}\right): 2.65\left(\mathrm{~m}, 6 \mathrm{H}, 3 \times \mathrm{CH}_{2}-\mathrm{N}\right) ; 3.67$

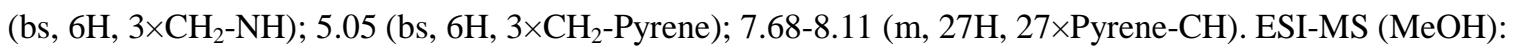
positive ion mode $(\mathrm{m} / \mathrm{z})$ : $966.2\left(\mathrm{M}+\mathrm{H}^{+}\right)$; negative ion mode $(\mathrm{m} / \mathrm{z})$ : $964.2(\mathrm{M}-\mathrm{H})^{-}, 1000.2\left(\mathrm{M}+\mathrm{Cl}^{-}\right)$. UV (3 $\mu \mathrm{M}$ in $\left.\mathrm{CH}_{3} \mathrm{CN}\right): 242 \mathrm{~nm}$ (0.4517), $266 \mathrm{~nm}$ (0.178047), $277 \mathrm{~nm}$ (0.244112), $315 \mathrm{~nm}$ (sh, 0.088458), $328 \mathrm{~nm}$ (0.196298), $344 \mathrm{~nm}$ (0.251476). Fluorescence ( $3 \mu \mathrm{M}$ in $\mathrm{CH}_{3} \mathrm{CN}, \lambda_{\text {ex }}=344 \mathrm{~nm}$ ): $377 \mathrm{~nm}$ (77510), $397 \mathrm{~nm}$ (109970), $477 \mathrm{~nm}(846610)$.

Tris-(2- (N'-pyren-1yl-methyl-guanidinium)-ethyl)- amine tri-chloride (2). The thiourea 5 (477.4 mg, $0.494 \mathrm{mmol}$ ) was dissolved in $5 \mathrm{ml} \mathrm{CH}_{2} \mathrm{Cl}_{2}$. After adding $128 \mu \mathrm{l} \mathrm{HI} \mathrm{(56 \%} \mathrm{in} \mathrm{water)} \mathrm{the} \mathrm{mixture} \mathrm{was} \mathrm{stirred}$ at room temperature for 30 minutes then $10 \mathrm{ml}$ ethanol was added. Subsequently the reaction vessel was placed in an ultrasonic bath for further 30 minutes, 5-HI was collected by filtration, washed with $\mathrm{Et}_{2} \mathrm{O}$ and finally dried at high vacuum to obtain $530.6 \mathrm{mg}$ hydroiodide salt of $\mathbf{5}$. The solid was suspended in $20 \mathrm{ml}$ $\mathrm{CH}_{2} \mathrm{Cl}_{2} / \mathrm{MeOH}$ (3:1), $850 \mu \mathrm{l} \mathrm{CH}_{3} \mathrm{I}$ was injected and the mixture was stirred (sealed tube) at room temperature for 70 hours when, according to ESI-MS all the thiourea groups had been completely methylated. All the volatiles were removed in vacuo and the resulting residue was dried under high vacuum yielding $645.4 \mathrm{mg}$ of the S-methyl-isothiourea intermediate $\mathbf{6} .622 \mathrm{mg} 6$ were transferred into a glas tube equipped with a J-Young valve, $10 \mathrm{ml}$ ammonia solution $(7 \mathrm{~N}$ in $\mathrm{MeOH})$ was added, the tube was sealed and the reaction was stirred at $55{ }^{\circ} \mathrm{C}$ over night. Most of the solid became soluble during the reaction. The reaction mixture was concentrated in vacuo and the residue $(670 \mathrm{mg})$ was purified by flash chromatography (silica gel, $\mathrm{CH}_{2} \mathrm{Cl}_{2} / \mathrm{MeOH}$ gradient from 490:10 to 300:200) to afford $290 \mathrm{mg}$ triiodide salt of 2 as a pale yellow solid (47\% over three steps). The counter anion was exchanged for chloride by ion exchange chromatography (Dowex 1×2, $\mathrm{Cl}^{-}$form, eluent: $\left.\mathrm{MeOH} / \mathrm{CH}_{3} \mathrm{CN}=4: 1\right) .{ }^{1} \mathrm{H}-\mathrm{NMR}\left(400 \mathrm{MHz}, \mathrm{CDCl}_{3}\right): 2.69$ (t, $6 \mathrm{H}, J=5.33 \mathrm{~Hz}, 3 \times \mathrm{CH}_{2}-\mathrm{N}$ ); 3.37 (t, $6 \mathrm{H}, J=5.50 \mathrm{~Hz}, 3 \times \mathrm{CH}_{2}-\mathrm{NH}$ ); 4.79 (bs, $6 \mathrm{H}, 3 \times \mathrm{CH}_{2}-$ Pyrene); 7.71-7.91 (m, 27H, 27×Pyrene-CH). ${ }^{13} \mathrm{C}-\mathrm{NMR}\left(500 \mathrm{MHz}, \mathrm{CDCl}_{3}\right)$ : 39.07 (3C, $\left.3 \times \mathrm{CH}_{2}-\mathrm{N}\right) ; 43.52$ (3C, $\left.3 \times \mathrm{CH}_{2}-\mathrm{Pyrene}\right)$; $52.39\left(3 \mathrm{C}, 3 \times \mathrm{CH}_{2}-\mathrm{NH}\right) ; 121.87,124.23,124.62,124.67,125.35,125.47,126.06,127.08,127.54,127.75$, 128.25, 130.37, 131.00, 131.18 (48C, 48×Pyrene-C, CH); 155.88 (3C, 3×C=NH). ESI-MS (MeOH): 
positive ion mode $(\mathrm{m} / \mathrm{z})$ : $915.3\left(\mathrm{M}+\mathrm{H}^{+}\right), 458.2\left(\mathrm{M}+2 \mathrm{H}^{+}\right) / 2,1043.2\left(\mathrm{M}+2 \mathrm{H}^{+}+\mathrm{I}^{-}\right)$; negative ion mode $(\mathrm{m} / \mathrm{z})$ : $913.3(\mathrm{M}-\mathrm{H})^{-}, 949.3\left({\left.\mathrm{M}+\mathrm{Cl}^{-}\right)}^{-}\right) 1041.2\left(\mathrm{M}+\mathrm{I}^{-}\right)$. UV $\left(3 \mu \mathrm{M}\right.$ in $\left.\mathrm{CH}_{3} \mathrm{CN}\right): 242 \mathrm{~nm}(0.416618), 265 \mathrm{~nm}$ (0.160328), $276 \mathrm{~nm}$ (0.266125), $314 \mathrm{~nm}$ (sh, 0.079722), $327 \mathrm{~nm}$ (0.17845), $343 \mathrm{~nm}(0.231993)$. Fluorescence ( $3 \mu \mathrm{M}$ in $\mathrm{CH}_{3} \mathrm{CN}, \lambda_{\mathrm{ex}}=343 \mathrm{~nm}$ ): $376 \mathrm{~nm}$ (335250), $396 \mathrm{~nm}$ (316140), $474 \mathrm{~nm}$ (1896021).

The preparation of vanadate stock solution. The $0.2 \mathrm{M}\left(n-\mathrm{Bu}_{4} \mathrm{~N}_{2} \mathrm{HVO}_{4}\right.$ aqueous solution was prepared according to the following equation:

$\mathrm{V}_{2} \mathrm{O}_{5}+4 \times n-\mathrm{Bu}_{4} \mathrm{~N} \cdot \mathrm{OH} \rightarrow 2 \times\left(n-\mathrm{Bu}_{4} \mathrm{~N}\right)_{2} \cdot \mathrm{HVO}_{4}+\mathrm{H}_{2} \mathrm{O}$

$90.94 \mathrm{mg} \mathrm{V} \mathrm{O}_{5}(0.5 \mathrm{mmol})$ and $1.5999 \mathrm{~g} n-\mathrm{Bu}_{4} \mathrm{~N} \cdot \mathrm{OH} \cdot 30 \mathrm{H}_{2} \mathrm{O}(2 \mathrm{mmol})$, then $1 \mathrm{ml}$ nano-pure water (or $\mathrm{D}_{2} \mathrm{O}$ for NMR titration) was mixed in a $5 \mathrm{ml}$ volumetric flask. The flask was placed in an ultra sonic bath for 30 minutes until a clear, colorless solution was obtained. The reaction volume was then adjusted to $5 \mathrm{ml}$ by adding water ( or $\mathrm{D}_{2} \mathrm{O}$ ). This solution is ready to use and can be diluted to obtain the desired concentration in acetonitrile or water for titrations or catalytic reactions. The solution can be stored in the dark at room temperature under argon for one month.

UV-vis and fluorescence titration. The titration experiments were performed on a $3.6 \mathrm{ml}$ scale in 1-cm path quartz fluorescence cuvettes. The stock solution of $1.08 \mathrm{mM}$ (A) and $5.4 \mathrm{mM}$ (B) vanadate were prepared by dilution of $0.2 \mathrm{M}\left(n-\mathrm{Bu}_{4} \mathrm{~N}\right)_{2} \cdot \mathrm{HVO}_{4}$ water solution in acetonitrile. The proportional addition of the stock solution by syringe to $3.6 \mathrm{ml} 3 \mu \mathrm{M}$ solution of receptor 2 in a fluorescent cuvette gave rise to different ratio of vanadate to receptor at $0: 1,0.25: 1,0.5: 1,1: 1,1.5: 1,2: 1,3: 1,5: 1,8: 1,13: 1,23: 1$, and 43:1. The solution was stirred for 5 minutes to be equilibrated for every measurement. Below the ratio of 3:1, solution (A) was used, and solution (B) was used after > 3:1 in order to minimize the total volume of added vanadate solution. Therefore, the concentration of the receptor can be approximatively treated as constant. Both UV-vis and fluorescence spectra were recorded for every single ratio. $2 \mathrm{~nm}$ slid was adopted for both excitation and emission fluorescence spectra.

Binding studies with phosphate and pyrophosphate were performed in a similar way, and the commercially available $n-\mathrm{Bu}_{4} \mathrm{~N} \cdot \mathrm{H}_{2} \mathrm{PO}_{4}$ and $\left(n-\mathrm{Bu}_{4} \mathrm{~N}\right)_{3} \mathrm{HP}_{2} \mathrm{O}_{7}$ were used for preparing stock solutions.

The stoichiometry of complex formed between of host and guest molecules was determined by Job plot, which was generated by plotting molecular fraction $\chi\left([\text { host }]_{\text {total }} /\left([\text { host }]_{\text {total }}+[\text { guest }]_{\text {total }}\right)\right)$ against the relative UV or fluorescence intensity change $\left(\chi \times\left(\mathrm{I}_{\text {obs }}-\mathrm{I}_{\text {host }}\right)\right)$. The position of the maximum value of the relative chemical shift change is corresponding to the stoichiometry of the complex formation. For example, maximum at $\chi=0.5$ means 1:1 complex, since at that point, [host $]_{\text {total }}=[\text { guest }]_{\text {total }}$; on contrast, for 2:1 mode, the maximum should appear at $1 / 3$ when $2 \times[\text { host }]_{\text {total }}=[\text { guest }]_{\text {total }}$. For a sharp binding curve, the stoichiometry can also be judged from the position of the break point.

The UV or fluorescence intensity values were plotted against the value of $2 /$ vanadate ratio and the data were fitted to the appropriate function using proFit 5.1 (proFit ${ }^{\circledR}$ QuantumSoft) or Origin 7.0 SR0 (Origin ${ }^{\circledR}$ OriginLab Corporation). The binding constant was obtained from the fitting if the systemic error was acceptable. 


\section{NMR Titrations}

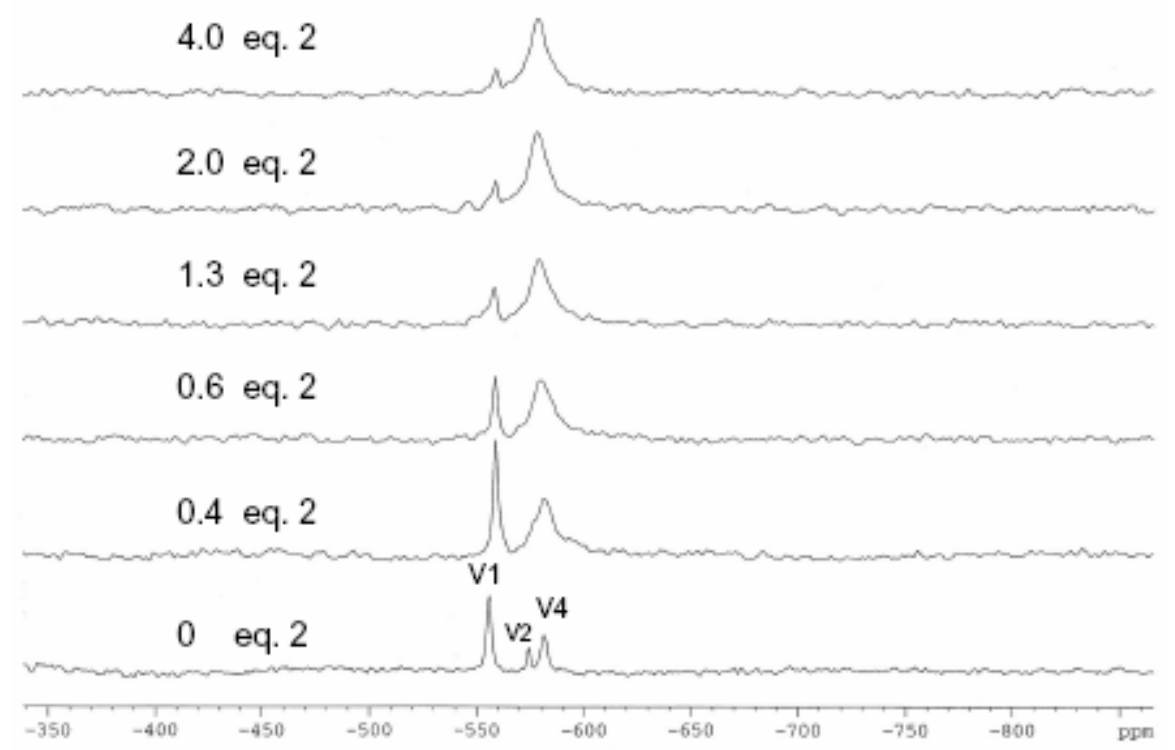

Figure 1. Compound 2 preferentially binds $\mathbf{V}_{2}$ over $\mathbf{V}_{1}$ as indicated by ${ }^{51} \mathrm{~V}-\mathrm{NMR}$ spectra of $0.5 \mathrm{mM}$ vanadate in DMSO-d6/ $\mathrm{D}_{2} \mathrm{O}$ (3:1); equivalents of $\mathbf{2}$ are related to the concentration of $\mathbf{V}_{\mathbf{1}}$.

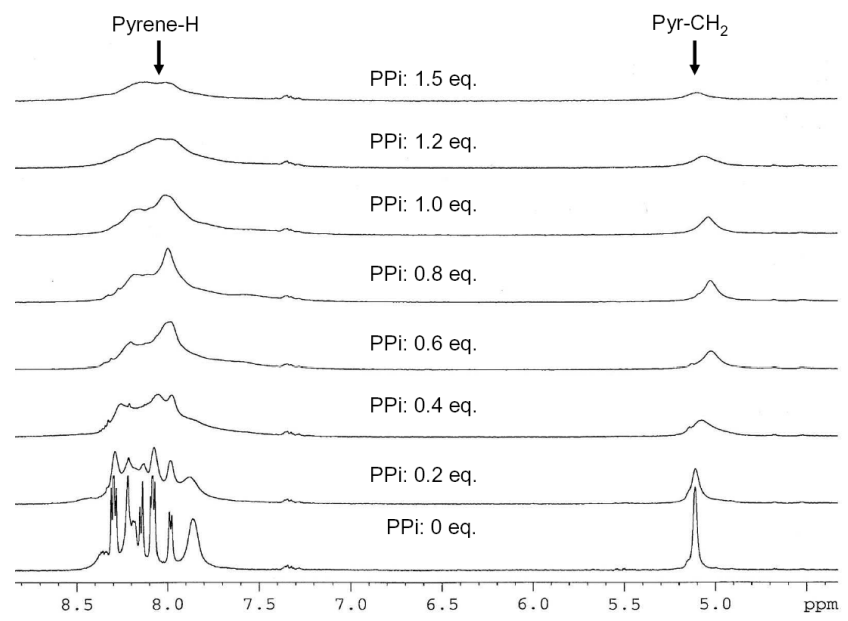

Figure 2. Part of the ${ }^{1} \mathrm{H}-\mathrm{NMR}$ spectra of $0.5 \mathrm{mM} 2$ in DMSO- $d_{6}$ with different molar ratios of pyrophosphate (PPi). 
Bromination of Monochloro dimedone (MCD) Followed by UV. The kinetic of catalytic experiments were performed on a $3.6 \mathrm{ml}$ scale in $1-\mathrm{cm}$ path quartz cuvettes. Spectra were collected on an Agilent 8453 Diode Array spectrophotometer under "kinetic mode" and cycle time was 2 seconds for all measurements. The bromination of MCD was followed by monitoring the intensity at $258 \mathrm{~nm}\left(\Delta \varepsilon=11.8 \mathrm{mM}^{-1} \mathrm{~cm}^{-1}\right)$. The stock solution of the reagents in acetonitrile were $54 \mathrm{mM} \mathrm{HBr}$ (or $n-\mathrm{Bu}_{4} \mathrm{~N} \cdot \mathrm{Br}$ and $\mathrm{HClO}_{4}$ ), $\mathrm{H}_{2} \mathrm{O}_{2}, \mathrm{MCD}$, TMB and $5.4 \mathrm{mM}$ vanadate.

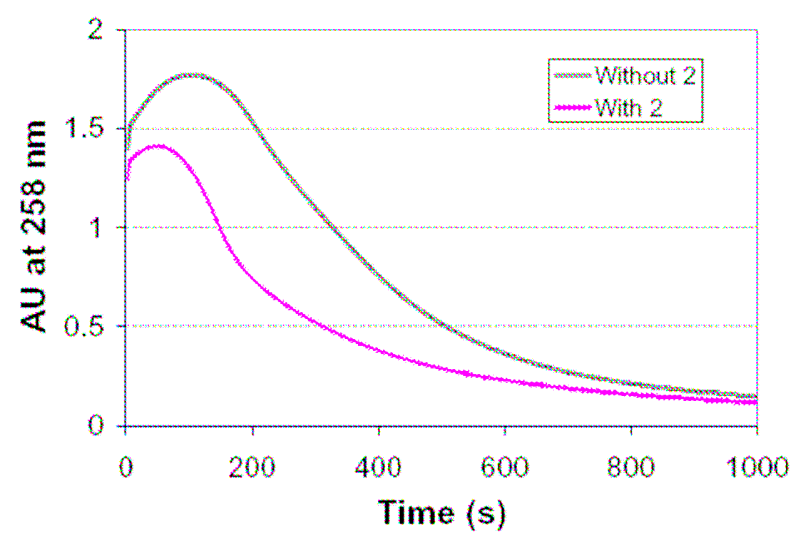

Figure 3. Catalytic bromination of MCD with or without $3 \mu \mathrm{M}$ 2. Reaction conditions are $6 \mu \mathrm{M}$ vanadate $\left(\mathbf{V}_{1}\right), 0.12 \mathrm{mM} \mathrm{MCD}, 0.3 \mathrm{mM} \mathrm{H}_{2} \mathrm{O}_{2}, 0.12 \mathrm{mM} \mathrm{HBr}$. The reaction was initiated by addition of $\mathrm{HBr}$. 